\title{
Level of Financial Literacy in Young Entrepreneurs: Study on Entrepreneurship-based University
}

Wirawan Endro Dwi Radianto, Tommy Christian Efrata, and Liliana Dewi

Universitas Ciputra, Surabaya, East Java, Indonesia

\section{Abstract}

This study is aimed to examine the level of financial literacy among young entrepreneurs. Young entrepreneurs in this study are active college students who take entrepreneurship education so that they have a real business besides their role as students. The novelty of this research lies in the research respondents, the aforementioned young entrepreneurs. The research method used was comparative descriptive, which includes investigating the level of financial literacy and then analyzing the difference in the level of financial literacy between male and female entrepreneurs.

Corresponding Author: Wirawan Endro Dwi Radianto wirawan@ciputra.ac.id

Received: 29 January 2019 Accepted: 27 February 2019 Published: 24 March 2019

Publishing services provided by Knowledge E

(c) Wirawan Endro Dwi Radianto et al. This article is distributed under the terms of the Commons Attribution License, which permits unrestricted use and redistribution provided that the original author and source are credited.

Selection and Peer-review under the responsibility of the 3rd ICEEBA Conference Committee.
A survey method was used in this study. The level of financial literacy uses the concept by Chen \& Volpe (1998), while the difference test uses the Mann-Whitney test. The results show that the level of young entrepreneurial literacy is in the moderate category. Of the four aspects studied, the highest aspect of financial literacy is the Insurance aspect, while the lowest is the investment aspect. The next result is that there is no difference in the level of financial literacy between young male and female entrepreneurs.

Keywords: financial literacy, young entrepreneur, gender

\section{Introduction}

Establishment of the entrepreneurship program is a specific educational program that teaches how students are specifically designed to become entrepreneurs. Therefore, the entrepreneurship education is not simply the education to know entrepreneurship but is an education that drives a person to be an entrepreneur. Therefore, education providers need to ensure that the curriculum, teaching methods, and environment provided to students are really suitable to direct students to become entrepreneurs. One method that is often used is the Experiential Based Learning method. Through this method, students will experience their business in real life because they have to have real business projects in order to facilitate the students in experiencing real business. 
They will experience financial loss and also financial profit. Thus, these students who run a business will hereinafter be referred to as young entrepreneurs.

In the process of starting-up the business, one of the important elements is their ability in financial management and their understanding of financial aspects of a business such as savings, loans, insurance, and investment. Therefore, young entrepreneurs must have financial skills, which will hereinafter be referred to as good financial literacy. Through good financial literacy, they will be able to find appropriate funding, manage existing funds effectively and efficiently, bear expenses appropriately, and even make the right investments. There are two roles that need to actually be carried out by young entrepreneurs, which are the role as a student who must complete his study and the role of a young entrepreneur who must run his business. Therefore, young entrepreneurs must carry out these two things at once to succeed as a student and as an entrepreneur.

Sabri et al. (2010) stated that the study period is the initial period for each student to manage their finances independently without parental supervision. This period is a transitional period of financial management from parents to the students. The lecture period is a critical time that students must manage finances properly through financial decisions. So that with limited income from parents, students must be able to manage finances properly in order for their lives to prosper and for them to be able to even prepare their future well. They are faced with increasing complexity in financial inclusion, especially regarding financial products, services, and markets, and bearing bigger financial risks in the future (Margaretha and Pambudhi, 2015). Students are one component of educated society that can contribute to the economy in the future because they will enter the workforce and begin to be independent in financial management. Therefore, the level of financial literacy among students will affect the level of financial literacy in Indonesia (Ariani and Susanti, 2015). Someone who has financial literacy will have a tendency to have responsible financial behaviors (Hilgert \& Holgart, 2003). Meanwhile, according to Hailwook (2007) financial literacy will influence how a person saves, borrows, invests, and manages finances. Hence, financial literacy affects students in their financial behavior (Laily, 2016).

The other side of young entrepreneurs is that they are businesspeople. As businessmen, they understand how to prepare financial statements for various purposes, such as funding, investment, or other financial actions (Dahmen \& Rodriguez, 2014). Moreover, they must possess good financial knowledge so that the business continues to grow and performs well. Aribawa's research (2016) found that businesspeople who have financial literacy will positively influence their business performance. The urgency of this research is that if young entrepreneurs do not have good financial literacy, then they certainly 
cannot manage their business well and even the sustainability of their business will be doubted. Thus, a research is needed to investigate the level of young entrepreneurial financial literacy. Furthermore, research on the level of financial literacy in business piloting seems to not have been done by many financial literacy researchers, so this research will contribute not only to the fields of finance and accounting but also to the field of entrepreneurship, especially in the aspect of business piloting. Although this study uses a single case study at a university, the results of this study will be very useful for the development of the entrepreneurial education curriculum, especially concerning entrepreneurial financing and accounting.

This study aims to find the level of financial literacy in young entrepreneurs who obtain entrepreneurship education in a designed manner. The difference between this study and other researches is that the research subjects in this study are young entrepreneurs who are designed to become entrepreneurs later in life, which is at the same time also serves as a point of novelty in this research. The researcher then conducts additional analysis to examine whether there are differences between in young male and female entrepreneurs regarding their financial literacy.

\section{Ease of Use}

\subsection{Literature review}

Research on the level of financial literacy in students has been carried out by the following researchers. Margaretha \& Pambudhi (2015) studied the level of student financial literacy and the results showed that the level of financial literacy was in the low category. The study also shows that gender affects financial literacy, but does not test whether there are differences between men and women regarding the level of financial literacy. Homan (2015), on the other hand, found that there was no difference in the level of financial literacy between male and female students. Ulfatun et al. (2016) examined the level of student financial literacy and found the level of financial literacy in the low category, similar to the findings of Margaretha \& Pambudhi (2015). Akmal \& Saputra (2016) examined the level of financial literacy of students at one of the universities in Padang and found that students were in the moderate category. On the other hand, Herawati (2017) found that the level of student financial literacy in a private university to still be in the low category. The study also found that gender had a significant effect on financial literacy but did not test whether there were differences in knowledge of financial literacy between genders. Research on the level of financial literacy conducted abroad was 
carried out by Ergun (2017), who examined the level of financial literacy of students in Estonia, Italy, Germany, the Netherlands, Turkey, Romania, the Russian Federation, and Poland. He found that all countries have moderate literacy levels, except Turkey. Some previous studies shows that the level of financial literacy is still inconsistent.

Financial literacy is an individual's knowledge in financial management to make financial decisions (Chen \& Volpe, 1998). In financial management there are four main aspects of financial literacy, namely knowledge of personal finance in general, savings and loans, insurance, and investment. The four aspects raised by Widdowson \& Hailwood (2007) are the same as Chen \& Volpe (1998), which are savings, loans, investing and managing finances. Capuano \& Ramsay (2011) combined the financial literacy competencies of several previous researchers into six core financial literacy competencies, namely: money basic, budgeting, saving and planning, loans, risk, and debt literacy. Money basic is about a person's basic abilities in financial management, budgeting is about how to allocate income and expenditure, saving and planning covers saving and financial planning, loans discusses one's knowledge about loans, risk is on understanding financial and investment products and a person's ability to protect himself from financial risk, and debt literacy discusses how a person understands debt management. The definition of financial literacy itself is financial knowledge and a person's ability to apply financial management capabilities (Lusardi \& Mitchell (2011). This definition develops into the life skills that everyone must have so that someone may increase his standard of living and survive in today's complex economic environment (Lusardi, 2012). The definition is broader and has an important meaning that financial literacy will enable a person to not only survive in a complex environment but also to improve his standard of living

\subsection{Methodology}

This research is a descriptive-comparative research using the survey method. The researcher distributed questionnaires to young entrepreneurs based on certain criteria, which are active college students who have a business and have gone through entrepreneurship education for at least five semesters. This research was conducted at Ciputra University as it is an entrepreneurial university.

This study is done using a descriptive analysis to find the level of financial literacy using the method of Chen \& Volpe (1998). Data obtained are from respondents' answers to multiple choice questions adopted from the researches of Chen \& Volpe (1998); Ulfatun et al. (2016); Putra et al. (2016); and Van Rooij et al. (2012). Respondents who answered correctly will be given a score of 1 , while the incorrect answer will be scored 
0 . The level of financial literacy of each respondent can be known by dividing the score obtained by the maximum number of score that can be obtained and then multiplying it by $100 \%$.

The researcher would then calculate the average value of the results in order to conclude the category of the financial literacy using the criteria by Chen \& Volpe (1998) as follows:

1. If the level of financial literacy is less than $60 \%$, then it is in the low category.

2. If the level of financial literacy is between $60 \%$ to $79 \%$, then it is in the moderate category.

3. If the level of financial literacy is higher than $79 \%$, then it is in the high category.

The researcher then analyzed the percentage of correct response in each question so that it can be known which aspects of financial literacy are mastered and which are not by most respondents. The correct response percentage is obtained by dividing the number of score obtained by each question with the maximum number of score that can be obtained, and then multiplied by $100 \%$. After analyzing the level of financial literacy in total, the researcher went to each of the financial literacy competencies, namely basic financial literacy, savings and loans, insurance activities and investment activities. Next, the researcher compared whether there were differences in the level of financial literacy between young male and female entrepreneurs. Tests were carried out using MannWhitney $U$ test analysis.

\section{Research Results}

The researcher distributed 300 questionnaires. Of this number, returned questionnaires that could be processed totaled at 165 questionnaires. From 164 questionnaires, there were 52 male respondents (31\%) and 112 female respondents (69\%). Systematics of writing in the data analysis and discussion starts from the analysis of the level of the young entrepreneur's financial literacy, based on the respondents. These three analysis aimed to describe the level of financial literacy of the total respondents and of each sex. Next, the researcher analyzed the correct responses of the four aspects of financial literacy, namely basic financial literacy, savings and loans, insurance, and investment. The aim is to describe in more depth what aspects are known to the respondents and which the respondents do not know. The last part is testing whether male and female young entrepreneurs differ in terms of the level of financial literacy. 
TABLE 1: Level of financial literacy among young entrepreneurs.

\begin{tabular}{lll}
\hline Category & Percentage & Information \\
\hline $\begin{array}{l}\text { General knowledge of } \\
\text { Finance }\end{array}$ & $72 \%$ & Moderate \\
\hline $\begin{array}{l}\text { General knowledge of } \\
\text { Savings and Loans }\end{array}$ & $77 \%$ & Moderate \\
\hline $\begin{array}{l}\text { General knowledge of } \\
\text { Insurance }\end{array}$ & $80 \%$ & High \\
\hline $\begin{array}{l}\text { General knowledge of } \\
\text { Investments }\end{array}$ & $68 \%$ & Moderate \\
\hline $\begin{array}{l}\text { Level of Financial } \\
\text { Literacy }\end{array}$ & $73 \%$ & Moderate \\
\hline
\end{tabular}

Table 1 shows that the level of financial literacy is in the moderate category (73\%). Furthermore, from the four financial literacy competencies, it turns out that investment occupies the lowest position, while insurance occupies the first position followed by savings and loans competencies and general knowledge of savings and loans. Of the four competencies, all competencies are in the moderate category and only insurance is in the high category, even though the score obtained is not high, and is within the lower range of the high category.

TABLE 2: Level of financial literacy based on the number of respondents.

\begin{tabular}{lll}
\hline Category & Amount & Percentage \\
\hline Low & 16 & $10 \%$ \\
Moderate & 103 & $63 \%$ \\
High & 45 & $27 \%$ \\
\hline Total & 164 & $100 \%$ \\
\hline
\end{tabular}

Table 2 shows the percentage of respondents in the low, moderate and high categories. Respondents in the low category are only about $10 \%$ of the total respondents, while respondents in the high category consist of only 45 respondents, which is around $27 \%$. The rest are included in the moderate category. From these data it appears that only a few respondents have a low level of financial literacy.

TABLE 3: Level of financial literacy among young male entrepreneurs.

\begin{tabular}{llcc}
\hline Gender & Category & Amount & Percentage \\
\hline \multirow{3}{*}{ Male } & Low & 8 & $15 \%$ \\
& Moderate & 30 & $58 \%$ \\
& High & 14 & $27 \%$ \\
\cline { 2 - 4 } & Sub Total & 52 & $100 \%$ \\
\hline \multirow{3}{*}{ Female } & Low & 8 & $7 \%$ \\
\cline { 2 - 4 } & Moderate & 73 & $65 \%$ \\
\cline { 2 - 4 } & High & 31 & $28 \%$ \\
\cline { 2 - 4 } & Sub Total & 112 & $100 \%$ \\
\hline Total & & 164 & \\
\hline
\end{tabular}

Table 3 shows the proportion of female entrepreneurs regarding to their level of financial literacy compared to male entrepreneurs, which is found to be better. Only 
half of male entrepreneurs have a moderate category of financial literacy, while female entrepreneurs who are in the moderate category reach 65\%. Likewise, it appears that the number of female entrepreneurs in the high category is higher than male entrepreneurs.

TABLE 4: Correct response on the general knowledge of finance.

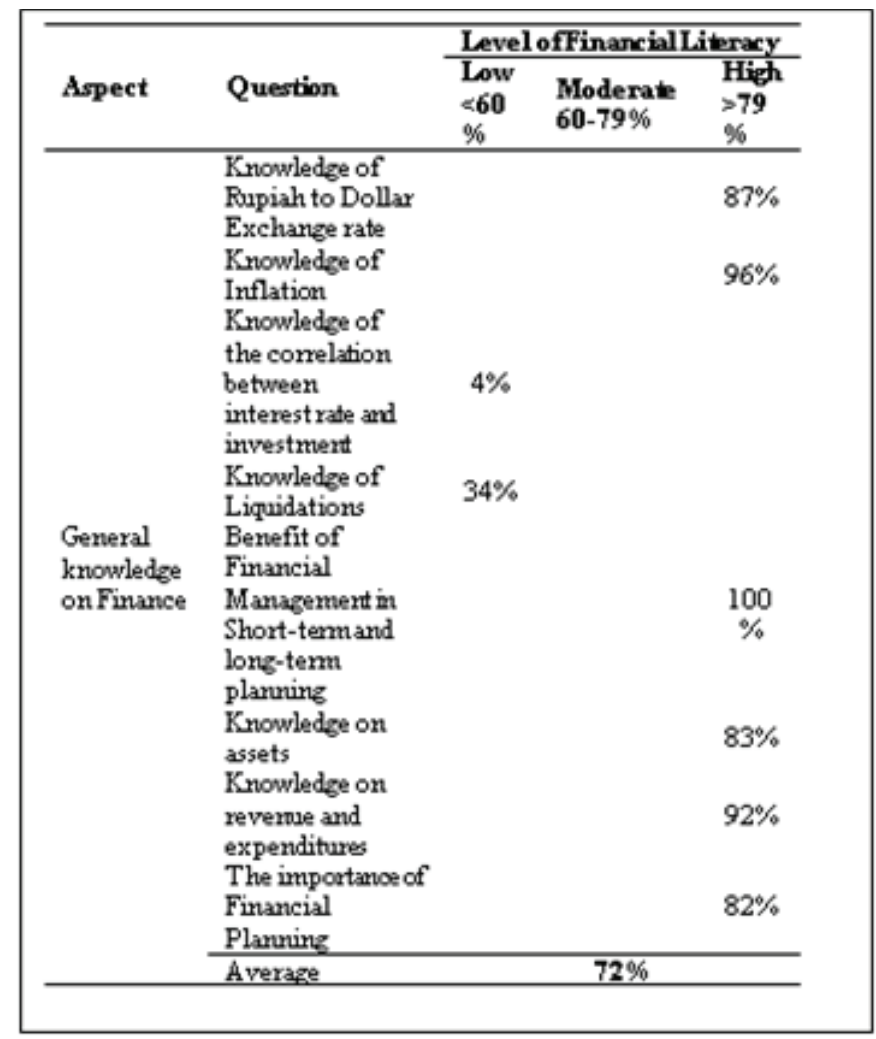

Table 4 shows all the questions regarding basic financial knowledge that respondents can answer correctly except for two questions that include knowledge about the relationship between interest rates and investment and knowledge about liquidation. From these data, if the respondent knows that the interest rate is related to investment behavior, it will shift the moderate category toward high category. Knowledge of the relationship of interest rates and investment was found to be very low in all four aspects. Instead, the respondents responded perfectly that financial management is very useful for short-term and long-term planning. This shows that almost all young entrepreneurs are aware that in business they must be able to manage finances well, not only in the short term, but also in the long run for their survival.

Table 5 shows that respondents already know the concept of savings, starting from the opening requirements, initial deposit, minimum balance, savings interest costs, and the benefits of saving. However, they still do not understand the calculations of interest and the time value of money. Regarding loans, respondents are included in the moderate 
TABLE 5: Correct response on savings and loans.

category. Since $68 \%$ of the respondents answered correctly, it can be indicated that almost all respondents already understand banking products.

TABLE 6: Correct response on insurance aspect.

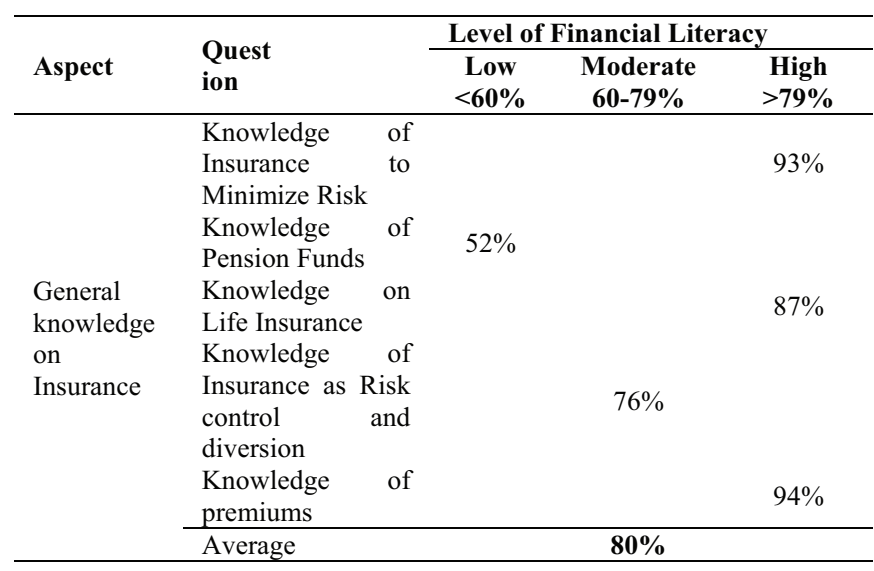

Respondents of this study had enough understanding regarding the concepts of insurance. They know the functions of insurance and its benefits. However, almost half of the respondents still do not understand pension funds. Respondents know that the function of insurance is to minimize risks and to divert business risks.

The investment aspect (Table 7) is the lowest aspect compared to the other three aspects. Although the young entrepreneurs already know about the concept of investment, there are three questions that are difficult to be answered by the respondents, namely when to invest, investment products, investment portfolios, and the relationship 
TABLE 7: Correct response on investment aspect.

between bonds and interest rates. However, respondents know the basics of stocks because they may be common investment products.

Testing of Differences in Financial Literacy between Male and Female Entrepreneurs

Before the researcher conducted a difference test, the researcher conducted a normality test to determine whether to use parametric or non-parametric statistics. The results of the normality test are shown in Table 8 below.

TABLE 8: Tests of Normality.

\begin{tabular}{|c|c|c|c|c|c|c|c|}
\hline \multirow[b]{3}{*}{ Nilai } & \multirow{3}{*}{$\begin{array}{l}\text { Grouping } \\
\text { Pria }\end{array}$} & \multirow{2}{*}{\multicolumn{2}{|c|}{$\begin{array}{l}\text { Kolmogorov- } \\
\text { Smirnova } \\
\text { Statistic df }\end{array}$}} & \multicolumn{4}{|c|}{ Shapiro-Wilk } \\
\hline & & & & Sig. & Stati & df & Sig. \\
\hline & & $\begin{array}{l}.117 \\
.112\end{array}$ & $\begin{array}{l}53 \\
112\end{array}$ & $\begin{array}{l}.066 \\
.001\end{array}$ & $\begin{array}{l}.953 \\
.974\end{array}$ & $\begin{array}{l}53 \\
112\end{array}$ & $\begin{array}{l}.038 \\
.026\end{array}$ \\
\hline
\end{tabular}

a. Lilliefors Significance Correction

Data shows that the value of sig. for male data is $0.066>0.05$ while for women is $0.001<0.005$. Because one of the data did not pass the normality test, it was concluded that the data was not normally distributed. So, the difference test used non-parametric, Mann-Whitney test. Table 9 below shows the Mann-Whitney test.

TABLE 9: Test Statistics.

\begin{tabular}{lr}
\hline & Fin Literacy Score \\
\hline Mann-Whitney U & 2850.500 \\
Wilcoxon W & 9178.500 \\
Z & -.411 \\
Asymp. Sig. (2-tailed) & .681 \\
\hline a. Grouping Variable: Gender
\end{tabular}


The results of Table 9 show the significance value of $0.681>0.05$, which means that there is no difference in the level of financial literacy between male and female entrepreneurs.

\section{Discussion}

The level of financial literacy in young entrepreneurs is in the moderate category. This is different from some of the findings of previous researchers, Margaretha \& Pambudhi (2015), Ulfatun et al. (2016), and Herawati (2017). In this case, respondents are young entrepreneurs who are always dealing with how to manage a business at any time. Of course, business management cannot be separated from financial management. Almost all of these young entrepreneurs make operational plans well as budgets for each semester. Therefore they are no stranger to budget management. The researcher had observed that all respondents came from upper middle class families demographically. This condition makes them understand financial management better aside from their daily business exposure. Akmal \& Saputra (2016) found that the socioeconomic status of parents is related to one's financial literacy. Someone with middle and upper economic status turns out to be more frequent in managing finances so that they indirectly have a higher level of literacy than people with middle-low income.

In the context of investment, which is the lowest category, the value $68 \%$ is most probably because not all students invest. Almost all respondents who invest in stocks or in hedge funds are male students while female students are still very much underinvested. This happens because female respondents are more than men, making investment scores relatively low. The interesting thing is that insurance occupies the highest category compared to other categories. The results of the observations showed that there were many students who became insurance agents in the research location, some of the students even had business as well as being insurance agents. This is the main reason why many respondents have understood the basics of insurance.

Young entrepreneurs seem to have understood that their ability to manage finances in both short and long term is very important for their business. They also really understand about savings. This is understandable because when they do business, the turnover and the profits they get are stored in their savings. So, they understand the terms of opening a savings account and the regulations of the savings and banking. However, there are still many of them who cannot calculate compound interest and the time value of money. This condition is in accordance with the findings on the investment aspect, which has the lowest category among the other three aspects, which is in the low category of $68 \%$. 
There are still many of those who have not invested yet. The results of investigations by the researcher indicate that they still need funding for their businesses for activities such as purchasing inventory items, purchasing equipment and supplies, opening outlets, and paying for monthly operating costs such as salary for employees and consumables. This condition seems to make them postpone investment because the concept of investment is to use unused funds. Because they have not focused on investment it is only natural that they do not really understand how to calculate investments which require expertise in compound interest calculations that take into account the time value of money. This condition causes many of the respondents to not know investment products other than stocks, mutual funds, and bonds. Likewise, the respondents also had not known about the concept of investment portfolios and the timing of when investments should be made.

Insurance knowledge is quite good because the insurance aspect turns out to have the highest category of the four aspects of financial literacy in this study. In this section, most respondents do not know about pension funds. This is natural because they are young entrepreneurs who, of course, have not thought about their old days. They still focus on how to start and develop their businesses. The researcher indicated that student knowledge about insurance was not obtained from lectures but from the practices they do. The researcher had observed that in the studied university, there were quite a number of students who became insurance agents. This condition is very possible because since the first semester students have been inspired to do business and one of the industries that is currently developing in Indonesia is the insurance industry. The Financial Services Authority (OJK) states that the insurance industry continues to grow in Indonesia (Hana, 2018).

The Difference Test Result between male and female young entrepreneurs shows that there is no difference in the level of financial literacy between male and female entrepreneurs. This study is consistent with the results of Wagland \& Taylor (2009), and Fonseca, et al. (2010), who found no differences in the level of financial literacy between men and women. Although according to Ariani \& Susanti (2015), there are biological differences between men and women such as the nature of the differences (men in decision-making focus more on logic while women would focus more on feelings) but the results of this study show different results. This is because male and female respondents have the same level of education and the same education empirically shows the same level of financial literacy. The results of this study indicate that a person's ability and intelligence in managing finances is not determined by their gender (Laily, 2016). Therefore, this study supports previous researches which found no differences in financial literacy 
between men and women (Rasyid, 2012; Wagland \& Taylor, 2009; Fonseca, et al., 2010; Laily, 2016).

\section{Conclusion}

This study uses young entrepreneurs as respondents, namely students who have businesses and experience entrepreneurship education that is designed. As an entrepreneur, it is fitting to have good financial literacy so that they can manage their business and ensure that their business grows. The results of this study indicate the level of young entrepreneurial literacy is included in the moderate category (77\%). Of the four aspects studied, the highest aspect of financial literacy is the insurance aspect $(80 \%)$ and the lowest is investment (68\%). The next result is that there is no difference in the level of financial literacy between young men and women entrepreneurs.

Suggestions for further research are that researchers can develop questionnaires from several previous researchers in the context of Asia or Indonesia, because several past studies conducted on financial literacy used questionnaires adopted from other countries, which means that there are several aspects that are not suitable for conditions found in Indonesia. Furthermore, the research sample should be expanded to include other universities that have entrepreneurship programs in order to better represent the findings of financial literacy in young entrepreneurs.

\subsection{Limitations}

The limitations of this study are the data collection process. Many activities from young entrepreneurs hampers the data collection process. The existence of an incomplete questionnaire reduces the number of questionnaires that can be processed, and it certainly affects the results of the study.

\subsection{Gratitude}

The author would like to thank the Ministry of Research and Technology and Higher Education Technology for the funds given to the research team through the Applied Higher Education Leading Research scheme for the 2018 fiscal year. 


\section{References}

[1] Akmal, H. and Saputra, Y. E. (2016). Analisis Tingkat Literasi Keuangan. Jurnal Ekonomi dan Bisnis Islam, vol. 1, no. 2, pp. 235-244.

[2] Ariani, N. A. and Susanti. (2015). Pengaruh Faktor Demografi Terhadap Financial Literacy Mahasiswa Fakultas Ekonomi Universitas Negeri Surabaya Angkatan 2012. Jurnal Mahasiswa Teknologi Pendidikan, vol. 3, no. 2, pp. 1-11.

[3] Aribawa, D. (2016). Pengaruh Literasi Keuangan Terhadap Kinerja Dan Keberlangsungan Umkm Di Jawa Tengah. Jurnal Siasat Bisnis, vol. 20, pp. 1-13.

[4] Capuano, A. and Ramsay, I. (2011). What Causes Suboptimal Financial Behaviour? An Exploration of Financial Litercy, Social Influences and Behavioural Economics. Melbourne: Corporate Law and Securities Regulation.

[5] Chen, H. and Volpe, R. P. (1998). An analysis of personal financial literacy among college student. Financial Services Review, vol. 7, no. 2, pp. 107-128.

[6] Dahmen, P. and Rodriguez, E. (2014). Financial literacy and the success of small businesses: An observation from a small business development center. International Journal of Numeracy, vol. 7, pp. 1-12.

[7] Ergun, K. (2017). Financial literacy among university students: A study in eight European countries. International Journal of Consumer Studies, vol. 42, pp. 2-15.

[8] Fonseca, R., Mullen, K. J., Zamaro, G., et al. (2010). What Explains the Gender Gap in Financial Literacy? The Role of Household Decision- Making (Working Paper WR762).

[9] Hailwood, D. W. A. K. (2007). Financial literacy and its role in promoting a sound financial system. Reserve Bank of New Zealand, vol. 70, pp. 37-47.

[10] Hana, O. D. B. (2018). Pertumbuhan Industri Asuransi Masih Signifikan Hingga Mei 2018 diakses dari. Retrieved from: http://finansial.bisnis.com/read/20180629/ 215/811256/pertumbuhan-industri-asuransi-masih-signifikan-hingga-mei-2018 (accessed September 2018).

[11] Herawati, N. T. (2017). Tingkat Literasi Keuangan Mahasiswa Serta Faktor-Faktor yang Mempengaruhinya. Proceeding SENARI, vol. 5, pp. 131-137.

[12] Hilgert, M. A. and Hogart, M. (2003). Household financial management: The connection between knowledge and behavior. Federal Reserve Bulletin, vol. 89, pp. 309-322.

[13] Homan, H. S. (April 2015). Comparative study of student financial literacy and its demographic factors, in First International Conference on Economics and Banking (ICEP15'). Retrieved from: http://atlantis-press.com 
[14] Laily, N. (2016). Pengaruh literasi keuangan terhadap perilaku mahasiswa dalam mengelola keuangan. Journal of Accounting and Business Education, vol. 1, no. 4.

[15] Lusardi, A. (2012). Numeracy, financial literacy, and financial decision-making. Paper presented at The Journal scholar Commons.

[16] Lusardi, A. and Mitchell, O. (2011). Financial literacy around the world: An overview. National Bureau of Economic Research Nomor, vol. 17107, pp. 1-17.

[17] Margaretha, F. and Pambudhi, R. A. (2015). Tingkat Literasi Keuangan pada Mahasiswa S-1 Fakultas Ekonomi. Jurnal Manajemen dan Kewirausahaan, vol. 17, no. 1, pp. 76-85.

[18] Putra, I. P. S., Ananingtiyas, H., Sari, D. R., et al. (2016). Pengaruh tingkat literasi keuangan, experienced regret, dan risk tolerance pada pemilihan jenis investasi. Journal of Business \& Banking, vol. 5, no. 2, pp. 271-282.

[19] Rasyid, R. (2012). Analisis Tingkat Literasi Keuangan Mahasiswa Program Studi Manajemen Fakultas Ekonomi Universitas Negeri Padang. Jurnal Kajian Manajemen Bisnis, vol. 1, no. 2.

[20] Sabri, M. F., MacDonald, M., Masud, J., et al. (2008). Financial behavior and problem among college student in Malaysia: Research and education implication. Consumer Interest Annual, vol. 5, no. 4, pp. 166-170.

[21] Ulfatun, T., Udhma U. S., and Dewi, R. S. (2016). Analisis Tingkat Literasi Keuangan Mahasiswa Fakultas Ekonomi Universitas Negeri Yogyakarta Tahun 2012-2014. PELITA, vol. 11, no. 2, pp. 1-13..

[22] Van Rooij, M. C., Lusardi, A., and Alessie, R. J. (2012). Financial literacy, retirement planning and household wealth. The Economic Journal, vol. 122, no. 560, pp. 449478.

[23] Wagland, S. P. and Taylor, S. (2009). When it comes to financial literacy, is gender really an issue? Australasian Accounting, Business and Finance Journal, vol. 3, no. 1, p. 3.

[24] Widdowson, D. and Hailwood, K. (2007). Financial literacy and its role in promoting a sound Financial system. Reserve Bank of New Zealand, vol. 70, no. 2, pp. 37-47. 